\title{
Securitization, Structured Finance, and Covered Bonds ${ }^{1}$
}

\author{
Steven L. Schwarcz
}

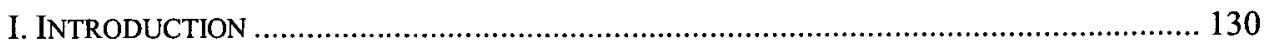

II. SECURITIZATION'S ROLE IN THE GLOBAL FINANCIAL CRISIS ....................................... 130

III. ADDRESSING SECURITIZATION'S PROBLEMS....................................................... 131

A. Problematic Asset Type ............................................................................. 133

B. Originate-to-Distribute Moral Hazard........................................................ 134

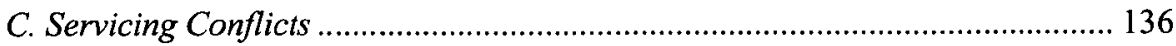

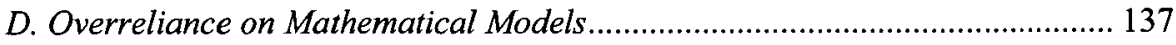

E. Overreliance on Rating-Agency Ratings ......................................................... 139

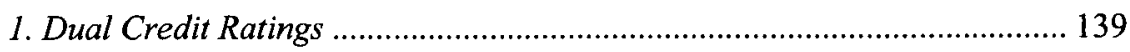

2. Investor Payment of Rating-Agency Fees ............................................... 140

IV. THE FUTURE OF SECURITIZATION ................................................................ 140

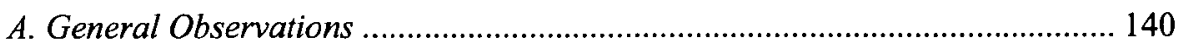

B. Alternatives to Securitization ................................................................... 142

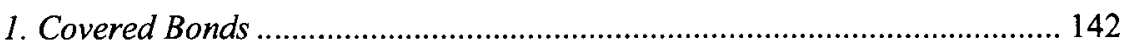

2. Comparing Covered Bonds with Chinese ABN ........................................... 144

3. Commercial Trusts Under Chinese Law ...................................................... 146

4. Trust Indentures ...................................................................................... 147

5. Trusts Used as Business Organizations ..................................................... 149

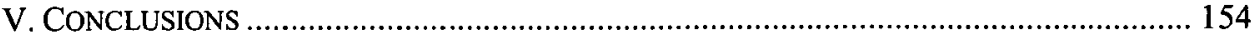

1. Copyright $\odot 2013$ by Steven L. Schwarcz.

2. Stanley A. Star Professor of Law \& Business, Duke University School of Law; Founding Director, Duke Global Capital Markets Center. E-mail: Schwarcz@law.duke.edu. I thank Liu Xiaoli and Ni Shoubin for excellent comments and Jonathan E. Cote for helpful research assistance. This Article is based in part on the following works: Steven L. Schwarcz, The 2011 Diane Sanger Memorial Lecture-Protecting Investors in Securitization Transactions: Does Dodd-Frank Help, or Hurt?, 2011 Diane Sanger Memorial Lecture (Mar. 28, 2011) [hereinafter Protecting Investors] (transcript available at www.sechistorical.org); Steven L. Schwarcz, The Conundrum of Covered Bonds, 66 Bus. LAw. 561 (2011) [hereinafter Covered Bonds]; Steven L. Schwarcz, Protecting Financial Markets: Lessons from the Subprime Mortgage Meltdown, 93 MNN. L. REv. 373 (2008) [hereinafter Protecting Financial Markets]; Steven L. Schwarcz, Commercial Trusts as Business Organization: An Invitation to Comparatists, 13 DUKE J. CoMP. \& INT'L L. 321 (2003); and Steven L. Schwarcz, The Future of Securitization, University of Oxford Leverhulme Lecture (Nov. 11, 2010) (transcript available at http://www.law.ox.ac.uk/published/leverhulme2010.php). 


\section{INTRODUCTION}

The author was hosted by the Shanghai Institute of Foreign Trade to present a series of high-level lectures on financial law at that institution as well as at Shanghai Jiao Tong University, Fudan University, China University of Political Science and Law, Peking University, and Tsinghua University. These lectures, presented in December 2012, focused on securitization, structured finance, and covered bonds, and they included related concepts from commercial trusts and shadow banking. This Article integrates the substance of those lectures.

\section{SECURITIZATION'S ROLE IN THE GLOBAL FINANCIAL CRISIS}

The securitization of subprime mortgage loans is widely viewed as a root cause of the global financial crisis. ${ }^{3}$ In the United States, there was significant government pressure on banks and other lenders to make home-mortgage loans to expand home ownership, even for risky borrowers. ${ }^{4}$ These subprime loans were often made, for example, to borrowers with little de facto income, anticipating that home-value appreciation would enable the borrowers to refinance to lower-rate mortgages. 5 Historically, home prices had generally been increasing in the United States since the Great Depression. ${ }^{6}$

But this model failed when, in 2007 and 2008 , home prices fell significantly. ${ }^{7}$ In one sense, the precipitous drop in home prices was unexpected-like Monty Python's skit, "Nobody expects the Spanish Inquisition."8 In another sense, though, "the fall arguably should have been anticipated based on the [earlier] liquidity glut and artificially low interest rates, driving up housing prices artificially."9

As a result of the fall in home prices, borrowers who were relying on refinancing for loan repayment could not refinance. ${ }^{10}$ Furthermore, many subprime mortgage loans had adjustable rates, which increased after an initial "teaser" period. ${ }^{11}$ Borrowers, some of whom could not afford the rate increases, had expected to refinance at lower interest

3. For an introduction to securitization, see STEVEN L. SCHWARCZ, STRUCTURED FNANCE: A GUIDE TO The Principles of ASSET Securitization (3d ed. 2002); Steven L. Schwarcz, The Alchemy of Asset Securitization, 1 STAN. J.L. BUS. \& FIN. 133 (1994) [hereinafter Alchemy]; Protecting Investors, supra note 2.

4. Protecting Investors, supra note 2. Arguably, the fall was exacerbated by the fact that mortgage lenders could make money on the volume of loans originated.

5. Id.

6. Id.

7. Id.

8. Monty Python's Flying Circus: The Spanish Inquisition (BBC television broadcast Sept. 22, 1970) (describing an unrelated instance when an event was unexpected).

9. Steven L. Schwarcz, Understanding the Subprime Financial Crisis, 60 S.C. L. REV. 549, 551 (20082009) [hereinafter Understanding the Subprime Financial Crisis] (describing the various failures that led up to the financial crisis).

10. Id. at 552-53.

11. How Lending Standard Changes Led to the Housing Boom/Bust, BIG PICTURE (Oct. 21, 2008, 7:21 AM), http://bigpicture.typepad.com/comments/2008/10/why-lending-sta.html (explaining that borrowers for low teaser rates were searched for and that this contributed to the collapse of 293 mortgage lenders). 
rates. ${ }^{12}$ Collapsing home prices stymied those expectations. ${ }^{13}$ For these reasons, many risky borrowers began defaulting. 14 "These defaults in turn caused substantial amounts of low-investment-grade-rated mortgage-backed securities to default and [the highest] AAA-rated securities to be downgraded." 15 This frightened investors, who believed that "investment grade" meant relative freedom from default, and that "AAA" meant ironclad safety. ${ }^{16}$ Investors started losing confidence in rating-agency ratings and started avoiding all types of rated debt securities. ${ }^{17}$

Fewer investors meant that the price of debt securities began falling. 18 "Falling prices meant that firms using debt securities as collateral had to mark them to market and put up cash-requiring the sale of more securities-which caused market prices to plummet further downward in a death spiral." 19 The U.S. government's refusal in midSeptember 2008 to save Lehman Brothers, and its resulting bankruptcy, added to this cascade. ${ }^{20}$ Investors lost all confidence in debt markets, and even the short-term commercial paper market virtually shut down. ${ }^{21}$ The lack of debt financing meant that companies could no longer grow and, in some cases, even survive. That affected the real economy and led to the global financial crisis. ${ }^{22}$

\section{ADDRESSING SECURITIZATION'S PROBLEMS}

Because of its role in initially triggering the global financial crisis, securitization has been villainized. ${ }^{23}$ But prior to the crisis, and even now, securitization is one of the

12. Understanding the Subprime Financial Crisis, supra note 9, at 551 (describing when borrowers could not refinance).

13. Id.

14. Steven L. Schwarcz, Regulating Complexity in Financial Markets, 87 WASH. U. L. REV. 211, 217 (2009) [hereinafter Regulating Complexity in Financial Markets].

15. Understanding the Subprime Financial Crisis, supra note 9, at 552; see Steve Lohr, In Modeling Risk, the Human Factor Was Left Out, N.Y. TIMES, Nov. 5, 2008, at B1 (describing how the models failed to keep pace with the complex securities); Steven L. Schwarcz, The Future of Securitization, 41 CONN. L. REV. 1313, 1323-24 (2009) [hereinafter The Future of Securitization] (explaining that the overuse of securitization models has caused inaccuracy and thus has increased the uncertainty of investors in regards to securities).

16. Understanding the Subprime Financial Crisis, supra note 9, at 552.

17. See Steven L. Schwarcz, Private Ordering of Public Markets: The Rating Agency Paradox, 2002 U. ILL. L. REV. 1 (2002) [hereinafter Private Ordering of Public Markets], available at http://ssrn.com/abstract_id= 267273 (providing an explanation of rating agencies and their ratings).

18. Understanding the Subprime Financial Crisis, supra note 9, at 552.

19. Id.

20. Id. Also, restructuring can involve difficult decisions. For example, in a mortgage securitization transaction in which cash flows deriving from principal and interest are separately allocated to different investor classes, or tranches, a restructuring that reduces the interest rate would adversely affect investors in the interestonly tranche (and likewise, a restructuring that reduces principal would adversely affect investors in the principal-only tranche).

21. Understanding the Subprime Financial Crisis, supra note 9, at 552.

22. Id. at 553 .

23. Thus, securities backed by financial assets are usually more creditworthy than securities issued directly by the originators. STEven L. Schwarcz, Structured FINANCE: A Guide to THE PrinCIPLES OF ASSET SECURITIZATION $§ 1: 3$ (3d ed. Supp. 2010) (explaining that except for the most highly rated issuers, securities issued in securitization transactions typically are more highly rated than the issuer's own debt securities - and that, even where the latter are more highly rated, securitization provides additional market flexibility to obtain financing). 
primary mechanisms by which companies can obtain financing from the capital markets, bypassing high-cost intermediaries such as banks-an approach known as "disintermediation." 24

As a tool for disintermediation, securitization can more precisely allocate risk with capital, avoiding middleman inefficiencies. It also can enable companies to access capital markets directly, in most cases at lower cost than the cost of issuing direct debt (such as bonds or commercial paper). "Moreover, when the securitized assets are loans [such as mortgage loans], securitization can help to transform the loans into cash from which banks and other lenders can make new loans." 25

These positives might be outweighed, however, by securitization's flaws, which were revealed by the global financial crisis. Whether securitization, even with the flaws, created net positive value is an unresolved question. My goal in this Article is not to attempt to answer that question. Instead, I examine how to overcome these flaws.

There are at least five potential flaws: subprime mortgages may be a problematic asset type that should not have been securitized; the originate-to-distribute model of securitization might create moral hazard; securitization can create servicing conflicts; securitization can foster overreliance on mathematical models; and investors in securitization transactions may over-rely on rating-agency ratings. ${ }^{26}$

This Article uses the following terminology. Subprime mortgage loans (also called subprime mortgages) are loans made to risky borrowers who use the proceeds to purchase homes and then mortgage the homes as collateral; because the borrowers are risky, the collateral is the primary source of repayment. ${ }^{27}$ "In the most basic form of mortgage securitization, mortgage-backed securities (MBS) are issued by a special-purpose vehicle (SPV), and payment on the securities is derived directly from collections on mortgage loans owned by the SPV." 28 In addition:

More complex forms of mortgage-backed securities include collateralized debt obligation ("CDO") securities in which payment derives directly from a mixed pool of mortgage loans and sometimes, also, other financial assets owned by the SPV; and 'ABS CDO' securities in which payment derives from MBS and CDO securities owned by the SPV (and thus indirectly from the mortgage loans and other financial assets underlying those owned securities). ${ }^{29}$

Subprime mortgage securitization can reference any of these financial products, so long

24. Id.

25. The Future of Securitization, supra note 15, at 1315 (2009).

26. Steven L. Schwarcz, Structured Finance: A Guide to the Principles of asset SeCURITIZATION $\$ \S 1: 1,11: 1-2$ (3d ed. Supp. 2010).

27. Although subprime mortgage loans were sometimes made to affluent borrowers in amounts that may be difficult for such borrowers to repay, a significant amount of subprime mortgage loans were made to nonaffluent or poor borrowers. To some extent, this followed the U.S. government's strong encouragement of lenders to make mortgage loans to low-income-often disproportionately minority - borrowers; to some extent, it also may have reflected greed due to the high interest rates charged to risky borrowers. Understanding the Subprime Financial Crisis, supra note 9, at 551.

28. The Future of Securitization, supra note 15, at 1316; see also Protecting Financial Markets, supra note 2, at 376-77 (discussing SPVs).

29. The Future of Securitization, supra note 15, at 1316; Private Ordering of Public Markets: The Rating Agency Paradox, supra note 17, at 2-5, 8. 
as all or a material portion of the underlying financial assets consist of subprime mortgages.

Next, consider these five potential flaws, examining what went wrong and what needs to be fixed.

\section{A. Problematic Asset Type}

The failure of subprime mortgage securitization was caused by its almost absolute dependence on home appreciation. ${ }^{30}$ Some believe this type of particular sensitivity to declines in house prices was unique. ${ }^{31}$ "From that perspective, parties structuring securitization transactions can minimize future problems by excluding, or at least limiting and better managing, subprime mortgage loans as an eligible type of underlying financial asset, and also by conservatively assessing the payment prognosis for other types of financial assets underlying securitizations." 32 This is important not only to protect the integrity of securitization transactions but also to avoid the unintended consequence that securitization of a problematic asset type can motivate greater origination of that asset type. However:

This is not to say these procedures will be failsafe. Parties to and investors in securitization transactions must always be diligent to recognize and try to protect against the possibility that the underlying financial assets might, as in the case of subprime mortgage loans, fail in unexpected ways. What would happen to automobile loan securitizations, for example, if a technological innovation makes cars obsolete, depriving even financially healthy borrowers of the incentive to repay their loans? The invention of a new form of personal transportation is at least as plausible as the idea that home prices-which generally had only risen since the 1930 s-would suddenly collapse in value at a rate higher than that seen during the Great Depression as happened in the global financial crisis. ${ }^{33}$

The global financial crisis also teaches us the danger of mixing politics and finance. "Before the crisis, there was political pressure to securitize risky subprime mortgage loans to facilitate financing for the poor." 34 We could also see the same type of political pressure, for example, to securitize risky microfinance loans to facilitate financing for the poor and disadvantaged. 35

Finally, the impact of the failure of subprime mortgage securitization should be viewed in its larger context. Subprime mortgage loans usually constituted only a small

30. The Future of Securitization, supra note 15, at 1317.

31. Gary B. Gorton, The Panic of 200767 (Yale ICF, Working Paper No. 08-24, 2008), available at http://papers.ssm.com/sol3/papers.cfm?abstract_id=1255362.

32. The Future of Securitization, supra note 15, at 1317-18. Assessments of payment prognosis should, at bottom, strive to be as accurate as possible. But where a prognosis has a margin of error, perhaps one should err, in structuring transactions, on the more conservative side of that margin.

33. Id.

34. The Future of Securitization, supra note 15, at 1318; see also Understanding the Subprime Financial Crisis, supra note 9, at 549-72 (discussing the danger of mixing politics and finance).

35. Id. 
part of the pools of financial assets backing mortgage-backed securities. ${ }^{36}$ It was irrational panic that caused the market prices of those securities to collapse, in many cases arguably substantially below the intrinsic value of the mortgage loans underlying those securities. But that collapse became a self-fulfilling prophecy by freezing the debt markets, thereby negatively impacting the real economy and causing even prime mortgage borrowers to lose their jobs and default. ${ }^{37}$

\section{B. Originate-to-Distribute Moral Hazard}

As I previously indicated:

Some argue that securitization facilitated an undisciplined mortgage lending industry. By enabling mortgage lenders to sell off loans as they were made (a concept called "originate-to-distribute" or "originate-and-distribute"), securitization is said to have created moral hazard since these lenders did not have to live with the credit consequences of their loans. Mortgage underwriting standards therefore fell, exacerbated by the fact that mortgage lenders could make money on the volume of loans originated. ${ }^{38}$

I find the moral hazard argument weak. Mortgage underwriting standards may have fallen, but there are other explanations. For example, lower standards may well reflect distortions caused by the liquidity glut of that time, in which lenders competed aggressively for business, allowed otherwise-defaulting home borrowers to refinance, and (in the corporate lending context) even made so-called "covenant-lite" loans. The fall in standards may also reflect conflicts of interest between lending firms and their employees in charge of setting those standards, such as where employees were paid for booking loans regardless of the loans' long-term performance.

Blaming the originate-to-distribute model for lower mortgage underwriting standards also does not explain why standards were not similarly lowered for originating non-mortgage financial assets used in other types of securitization transactions. Nor does it explain why the ultimate beneficial owners of the mortgage loans-the investors in the

36. This was the author's experience.

37. See supra notes 3-5 and accompanying text (explaining the sequence of events leading to the global financial crisis). I explain these events in more detail in Understanding the Subprime Financial Crisis, supra note 9.

38. The Future of Securitization, supra note 15, at 1318; see, e.g., Martin Feldstein, How To Stop the Mortgage Crisis, WALL ST. J., Mar. 7, 2008, at A15, available at http://www.nber.org/ feldstein/wsj03072008.pdf (describing lax lending standards that gave rise to mortgages with loan-to-value ratios of nearly $100 \%$ and citing the 1.8 million mortgages then in default); David Henry \& Matthew Goldstein, The Bear Flu: How It Spread, BUS. WK., Dec. 31, 2007, at 30, available at LEXIS, News Library, BUSWK File (arguing that the distance between mortgage-loan originators and the ultimate holders of the loans encouraged lax lending); $c f$. John C. Dugan, Speech at The Annual Convention of The American Bankers Association (Oct. 8, 2007), at 5, available at http:/www.occ.treas.gov/news-issuances/speeches/2007/pubspeech-2007-109.pdf (observing that with the increasing use of the originate-to-distribute model of lending, lending standards shifted from evaluating the likelihood of repayment to evaluating the likelihood that the loan could be sold). But cf. Gorton, supra note 31, at 67-68 (disagreeing with this explanation, although observing that the originate-to-distribute model and resulting moral hazard are the "dominant explanation" for the financial panic); Effi Benmelech et al., Securitization Without Adverse Selection: The Case of CLOs, available at http://ssrn.com/abstract_id=1344068 (finding, empirically, that bank loans that are securitized perform no worse than bank loans that are held). 
mortgage-backed securities-did not govern their investments by the same strict lending standards that they would observe but for the separation of origination and ownership.

Whatever the cause of falling mortgage underwriting standards, the originate-todistribute model may need fixing to avoid its perception as the cause. There is little question, though, that the model should remain basically intact; it is critical to the underlying funding liquidity of banks and corporations, and empirical evidence tentatively indicates that it creates net value. ${ }^{39}$ The goal therefore should be to minimize any potential moral hazard resulting from the originate-to-distribute model without undermining the model's basic utility.

There are various ways this might be done. Potential moral hazard problems could be managed, for example, by requiring mortgage lenders and other originators to retain some realistic risk of loss. This is the central approach of the Dodd-Frank Wall Street Reform and Consumer Protection Act in the United States, which requires sellers of securitization products to retain a minimum unhedged position in each class of securities they sell-the so-called "skin in the game." 40

I understand that the Chinese government is taking a similar, though apparently much stricter, approach: requiring sellers of securitization products to retain a minimum unhedged subordinated position when they sell securities. ${ }^{41}$ In comparison with U.S. law, which makes sellers take a material risk of loss pari passu with investor risk of loss, Chinese law makes sellers take a material risk of loss in which the sellers would suffer their loss before investors suffer any loss. This effectively makes sellers the guarantors of investors. It will be interesting to see whether the Chinese approach unduly discourages the origination and selling of securitization products.

All that may be needed is to ensure that sellers' interests become better aligned with the investors' interests, so that investors benefit from the sellers' better information. The Dodd-Frank Act's approach should achieve that limited goal. Query, however, the extent to which even that limited goal could create a "mutual misinformation" problem: that the unfounded optimism of sellers who do not fully understand their product could lull investors into buying the product.

Moral hazard problems also could be managed by regulating loan underwriting standards. The United States took this type of approach, for example, in response to the margin loan underwriting failures that helped trigger the Great Depression. ${ }^{42}$ When stock

39. See, e.g., Protecting Financial Markets, supra note 2, at 388 n.74 (citing Joseph R. Mason, Assoc. Professor of Fin. \& LeBow Research Fellow, LeBow Coll. of Bus., Drexel Univ., Mortgage Loan Modification: Promises and Pitfalls, Presentation to the Federal Reserve Bank of Cleveland (Nov. 20, 2007) (presentation notes on file with author) (showing that $58 \%$ of mortgage liquidity in the United States and $75 \%$ of mortgage liquidity in California has come from structured finance).

40. See Dodd-Frank Act, 12 U.S.C. $\S \S 5301,941(\mathrm{~b}), 15 \mathrm{G}$ (2010) (directing the SEC to require sponsors of asset-backed securities to retain at least five percent of the credit risk of the underlying assets).

41. I have been informed that, in May 2012, People's Bank of China ("PBC"), the China Banking Regulatory Commission, and the Ministry of Finance of the People's Republic of China jointly released a notification, which requires that originators in securitization transactions shall retain a minimum quantity of subordinated tranche equal to about five percent of the total issue volume of each securitization project, and that the holding period shall not be shorter than the duration of the subordinated tranche. E-mail from Liu Xiaoli, Assoc. at the Zhong Lun Law Firm in Beijing, and LL.M. candidate 2013, Duke Law Sch., to author (Sept. 26, 2012) (on file with author).

42. Protecting Financial Markets, supra note 2, at 389-90. 
values began depreciating in 1929, margin loans (that is, loans to purchase publicly listed stock) became undercollateralized, resulting in a high loan default rate, which in turn caused bank lenders to fail. ${ }^{43}$ To protect against a recurrence of this problem, the Federal Reserve promulgated margin regulations $\mathrm{G}, \mathrm{U}, \mathrm{T}$, and $\mathrm{X}$, requiring margin lenders to maintain minimum two-to-one collateral coverage. ${ }^{44}$

A similar type of approach applied to home-mortgage loans would certainly protect against a repeat of the crisis. ${ }^{45}$ That protection would come at a high price, though, potentially impeding and increasing the cost of home ownership and imposing an administrative burden on lenders and government monitors. 46

\section{Servicing Conflicts}

Mortgage securitization makes it difficult to work out problems with the underlying mortgage loans because the beneficial owners of the loans are no longer the mortgage lenders but a broad universe of investors in the mortgage-backed securities. Servicers theoretically bridge the gap between investors (as beneficial owners of the loans) and the mortgage lenders, retaining the power to restructure the underlying loans "in the best interests" of those investors; but the reality is problematic. 47

Servicers may be reluctant to engage in a restructuring, for example, if there is uncertainty whether their costs will be reimbursed; whereas foreclosure costs are relatively minimal. ${ }^{48}$ Servicers may also prefer "foreclosure over restructuring" because foreclosure "is more ministerial and thus has lower litigation risk." 49 Restructuring can involve difficult decisions. For example, in a mortgage securitization transaction in which "cash flows deriving from principal and interest are separately allocated to different investor" classes, or tranches, "a restructuring that reduces the interest rate would adversely affect investors in the interest-only tranche" (and likewise, a restructuring that reduces principal would adversely affect investors in the principal-only tranche)..$^{50}$

These problems can, and in the future should, be fixed. Parties should write underlying deal documentation that sets clearer and more flexible guidelines and more certain reimbursement procedures for loan restructuring, especially when restructuring appears to be superior to foreclosure. ${ }^{51}$ Parties also should try to minimize allocating

43. Id.

44. 12 C.F.R. $§ 221.7(a)$ (2008); Protecting Financial Markets, supra note 2, at 389-90 (2008).

45. Id. at 390 .

46. Id. There could be appropriate roles, however, for this type of approach. In the United States, for example, mortgage lending will be strongly driven by what is known as the Qualified Mortgage (QM) definition for making mortgage loans. See Steven L. Schwarcz, Shadow Banking, Financial Markets, and the Real Estate Sector, 32 REV. BANKING \& FIN. L. 179, 183-84 (2012). Until the definition is finalized, parties cannot estimate credit cost or availability. Attempts to finalize the QM definition face an inherent tension, however, between protecting borrowers while ensuring reasonable credit availability. Id. I have argued that one way to help resolve that tension would be to allow a definitional alternative option for a QM loan, based on the loan-tovalue ratio. Id. For example, there could be a non-exclusive regulatory safe harbor if the collateral value is at least $1 \mathrm{X}$ times the loan principal. This would be somewhat analogous to the two-to-one margin requirement. Id.

47. Protecting Investors, supra note 2.

48. Id. at $392-93$.

49. Id. at 393 .

50. Id.

51. Id. 
cash flows to investors in ways that create conflicts. ${ }^{52}$ Furthermore, I have argued that non-conflicted servicers that engage in restructuring in good faith should be protected, perhaps akin to the type of protection afforded corporate directors under a business judgment rule. 53

I understand that in all major securitization transactions to date in China, the servicers-absent their resignation or dismissal, which has never happened-are the original owners of the loans. ${ }^{54}$ Even where the original owners service the loans, however, the servicing problems described above could arise. That is because these problems result from lack of clarity about a servicer's responsibility to investors, reimbursement standards that unfairly favor foreclosure over restructuring, conflicts among investor rights, and exposure of servicers to investor lawsuits. On the other hand, requiring the original owners to service the loans would not necessarily bring efficiency if the servicing abilities of those owners are not as good as the abilities of firms that professionally engage in servicing loans.

\section{Overreliance on Mathematical Models}

"To some extent the subprime crisis resulted from an abandonment of common sense and an overreliance on complex mathematical models." 55 Models are essential to securitization because of the need to statistically predict what future cash flows will become available from the underlying financial assets to pay the mortgage-backed securities. ${ }^{56}$ There are benefits as well as hindrances to models. "Models can bring insight and clarity. If the model is realistic and the inputted data are reliable, models can yield accurate predictions of real events. However, if the model is unrealistic or the inputted data are unreliable, models can be misleading-creating the danger of 'garbage in, garbage out.,"57

Subprime mortgage securitization models, like value-at-risk $(\mathrm{VaR}){ }^{58}$ relied on assumptions and historical data that, in retrospect, turned out to be incorrect and therefore

52. Protecting Investors, supra note 2, at 393.

53. See Steven L. Schwarcz \& Gregory M. Sergi, Bond Defaults and the Dilemma of the Indenture Trustee, 59 ALA. L. REV. 1037 (2008) (touching on the benefits of applying a business judgment rule to indenture trustees).

54. E-mail from Liu Xiaoli, Assoc. at the Zhong Lun Law Firm in Beijing, and LL.M. candidate 2013, Duke Law Sch., to author (Nov. 11, 2012) (on file with author).

55. The Future of Securitization, supra note 15, at 1323 (emphasis added); cf. Karl S. Okamoto, After the Bailout: Regulating Systemic Moral Hazard, 57 UCLA L. REV. 183, 211 (2009) (observing that underlying the subprime financial crisis "was an enormous faith in the market's ability to analyze and measure risk"). Some of the overreliance may reflect that the complexity of the mortgage-backed securities made it difficult for investors to fully appreciate the risks they were incurring, tempting them to rely on such imperfect substitutes as ratingagency ratings and the results of mathematical models. Cf. Regulating Complexity in Financial Markets, supra note 14, at 232-40 (discussing why disclosure failed in the subprime crisis and the consequences of such failure).

56. My use of the term "mortgage-backed securities" is meant to be illustrative, not exclusive; securitization embraces securities backed by any form of financial assets.

57. The Future of Securitization, supra note 15 , at 1323.

58. Dodd-Frank's attempt to fix the traditional conflict might actually backfire. Recent research by Professor Iman Anabtawi at UCLA suggests that shareholders, even more than senior executives, want companies to take risks. 
made the valuations incorrect. ${ }^{59}$ The securitization models also incorrectly assumed that housing would not depreciate in value to the levels later seen. Valuation errors were compounded to the extent mortgage loans increasingly were made with innovative terms, such as adjustable rates, low-to-zero down payment requirements, interest-only payment options, and negative amortization. These terms were so complex that some borrowers did not fully understand the risks they were incurring. "As a result, they defaulted at a much higher rate than would be predicted by the historical mortgage-loan default rates relied on by loan originators in extending credit." 60

Overreliance on models has also occurred when the market lacks information:

Securitization models also have been used, sometimes erroneously, to substitute for real market information. ${ }^{61}$ For example, some highly-leveraged ABS CDO securities did not have an active trading market, so investors instead relied on mark-to-model valuation of these securities. When assumptions underlying the models turned out to be wrong, investors panicked because they did not know what the securities were worth. 62

It is nonetheless important to keep in mind that overreliance can be at least partly selfcorrecting:

In theory, this overreliance on mathematical models is self-correcting because the global financial crisis, by its very existence, has shaken faith in the market's ability to analyze and measure risk through models. ${ }^{63}$ Securitization products are likely to be confined, at least in the near future, to those that can be robustly modeled. The only question will be the longevity of the lesson that future risks cannot always be predicted through mathematical models. ${ }^{64}$

59. Protecting Financial Markets, supra note 2, at 398; see also Eugene Ludwig, Founder and CEO, Promontory Fin. Grp., 10th William Taylor Memorial Lecture at the Intemational Conference of Banking Supervisors 3 (transcript available at http://dev.promontory.com/assets/0/78/110/112/79f60323-36f6-4983babd-61274c17c373.pdf) (stating that "it is widely accepted" now that the subprime mortgage securitization models used by rating agencies and other market participants relied on "insufficient data and faulty assumptions"); The Future of Securitization, supra note 15, at 1323

60. The Future of Securitization, supra note 15, at 1324; cf. Subprime Mortgage Market Turmoil: Examining the Role of Securitization: Hearing Before the S. Subcomm. on Securities, Insurance and Investments, 110th Cong. 3-4 (2007) (statement of Kurt Eggert, Professor of Law, Chapman Univ. Sch. of Law), available at http://banking.senate.gov/public/_files/eggert.pdf; Edward Golding et al., Imperfect Information and the Housing Finance Crisis, JOINT CENTER FOR HOUSING STUD. HARV. U. (Feb. 1, 2008),

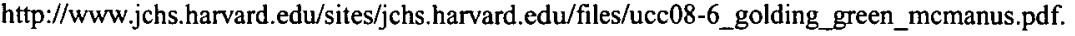

61. The Future of Securitization, supra note 15, at 1324.

62. Id.

63. Cf. Okamoto, supra note 55 , at 211 (discussing the overreliance on faulty risk models by investors); Larry Light, Bondholder Beware: Value Subject To Change Without Notice, Bus. WK., Mar. 29, 1993, at 34, available at http://www.businessweek.com/stories/1993-03-28/bondholder-beware-value-subject-to-changewithout-notice (discussing that within years after the Marriott "split," investors favor higher interest rates over "event-risk" covenants, once the examples of events justifying the covenants have receded in memory).

64. The Future of Securitization, supra note 15 , at 1324. 


\section{E. Overreliance on Rating-Agency Ratings}

A fifth possible flaw is that investors in securitization transactions overrelied on rating-agency ratings. ${ }^{65}$ This calls into question the extent of appropriate reliance on ratings, and indeed the integrity of the ratings process itself. Although I do not have time to engage in a complete analysis of these issues, I would like to address at least two matters that are currently under discussion in China: the requirement of dual credit ratings for securitization projects and the encouragement of an investor-payment model for rating-agency fees.

At the outset, however, we need to remember that while rating agencies may not be perfect, the idea of rating agencies is important. Investors individually face relatively high costs to assess the creditworthiness of complex securities. Rating agencies can make this assessment on behalf of many investors, thereby achieving an economy of scale.

\section{Dual Credit Ratings}

I understand that Chinese government regulations are beginning to impose a requirement of dual credit ratings for securities issued in securitization transactions. The idea, apparently, is that two ratings are more likely to accurately reflect credit risk on the securities than a single rating. ${ }^{66}$ Although I may be misinformed, I am unaware of any similar legal requirements in the United States. It is not unusual, in my experience, for investors or underwriters to require dual ratings as a market condition, especially in public securitizations. Indeed, I would have thought that markets themselves are good indicators of when dual ratings are appropriate. A mandatory legal rule appears unnecessarily costly, effectively imposing two rating-agency fees rather than one, even when one rating - and thus one fee-would be sufficient.

The requirement of dual ratings should also be viewed from the perspective of the global financial crisis. Even if, prior to the crisis, the law required dual ratings for securities issued in securitization transactions, that would not have made a difference because all of the major rating agencies failed to foresee the problem. The real problem is that credit ratings are judgment calls made by human beings, and humans inevitably make mistakes and often tend to engage in herd behavior. ${ }^{67}$

65. For an analysis of the integrity of the rating process and of the extent that investors should appropriately rely on ratings, see Protecting Financial Markets, supra note 2, at 381. For an introduction to ratings, rating agencies, and the rating process, see Private Ordering of Public Markets, supra note 17, at 2-5, 8.

66. E-mail from Liu Xiaoli, supra note 54.

67. From another perspective, one might argue that rating agencies should be more conservative, or that government should mandate more conservative ratings. Overprotection, however, has a cost. If rating agencies had used more conservative models requiring greater overcollateralization, those models would have been decried as wasteful if housing prices had not collapsed. 


\section{Investor Payment of Rating-Agency Fees}

Issuers of securities, including securities issued in securitization transactions, normally pay rating agencies for rating those securities. ${ }^{68}$ This suggests that rating agencies may have assigned artificially high ratings due to conflicts of interest regarding compensation. On a technical level, of course, an issuer-pay model does create a conflict of interest. That conflict, however, may not be material because ratings are determined independently of the fee received. ${ }^{69}$ Furthermore, the reputational cost of a bad rating usually far exceeds the income received by giving the rating. ${ }^{70}$

For some types of mortgage securitization transactions, though, the conflict may have been more material than normal because ratings were given to numerous issuances of $\mathrm{CDO}$ and $\mathrm{ABS} \mathrm{CDO}$ securities, with each issuance (and rating) earning a separate fee. Assuming arguendo this created a material conflict, there is no easy solution. The question of who pays for a rating is difficult. Historically, rating agencies made their money by selling subscriptions, but that may not generate sufficient revenue to allow rating agencies to hire the top-flight analysts needed to rate complex deals.

More to the point, I do not believe an investor-pay model is the solution. Even if there were an easy way to get investors to pay for ratings, that might create the opposite incentive: to err on the side of low ratings in order to increase the rate of return to investors, thereby increasing the cost of credit to firms issuing the securities.

\section{THE FUTURE OF SECURITIZATION}

\section{A. General Observations}

Because securitization, properly utilized, is an efficient financial tool, its future should be assured no matter how investors or politicians might temporarily overreact. Nonetheless, in the near future at least, it is likely that securitization transactions will need to refocus on basic structures and asset types in order to attract investors.

To this end, there likely will (and, I believe, should) be an emphasis on cash-flow securitizations in which there are the traditional "two-ways out." An example of this would be the securitization of prime mortgages, in which payment can come from the borrower or the collateral. Furthermore, we are not likely to see many highly complex securitization products, like ABS CDO transactions, which magnify leverage. I understand that securitization projects in China have never gotten as complicated as these types of products, ${ }^{71}$ and that is certainly healthy. Nevertheless, I wonder whether China has gone too far in controlling the complexity of securitization.

For example, I have been informed that most Chinese securitization transactions do not use any external credit enhancement or liquidity support methods. ${ }^{72}$ From a societal perspective, however, credit enhancement more efficiently allocates risk by shifting risk

68. Private Ordering of Public Markets, supra note 17, at 15.

69. Id. at 16.

70. Id. at 14 .

71. E-mail from Liu Xiaoli, supra note 54.

72. E-mail from Liu Xiaoli, supra note 41. 
to parties with special securitization expertise and experience-who are thereby better able to understand and assess risks associated with securitization transactions. The more a credit enhancer understands and accurately assesses risk (in economic terms, this is called reducing information asymmetry), the more efficiently risk is allocated. Credit enhancement also creates an economy-of-scale benefit: even if the expertise and experience of some investors in a securitization transaction match that of the credit enhancer, those investors individually may not have sufficiently large investments at stake to make it economically worthwhile for them to evaluate the transaction.

Similarly, liquidity support would create value by enabling the securitization of relatively long-term financial assets funded by short-term debt securities. This is economically advantageous to firms because the interest rate on short-term debt is usually lower than that on long-term debt. ${ }^{73}$ For example, asset-backed commercial paper ("ABCP") securitization conduits routinely issue short-term commercial paper to fund long-term loans or other financial assets.

Admittedly, this can be a double-edged sword, ${ }^{74}$ insofar as the short-term funding of long-term projects creates an inherent risk as to whether maturing funding can be paid. ${ }^{75}$ But that risk is common in finance, even being a central characteristic of traditional banking; ${ }^{76}$ and it is liquidity itself that best mitigates the risk. ${ }^{77} \mathrm{~A}$ primary reason for liquidity support, as for credit enhancement, is economy of scale. ${ }^{78}$ Investors in short-

73. Short-term interest rates are usually lower because it is easier to assess short-term repayment risk than long-term repayment risk. Short-term rates may also be lower because the term structure of interest rates (also known as the yield curve) is usually increasing despite the fact that it represents the risk-free rate for various horizons.

74. That is, it has benefits but potential liabilities.

75. See, e.g., Steven L. Schwarcz, Regulating Shadows: Financial Regulation and Responsibility Failure 70 WASH. \& LEE L. REV. 1781, 1806 (discussing the risks and consequences if the firm defaults on paying debt); cf. Kyle Glazier, Bernanke: Financial Crisis Was a Structural Failure, BoND BUYER (Apr. 16, 2012), $\mathrm{http} / \mathrm{www}$.bondbuyer.com/news/Bernanke-speech-financial-crisis-structural-failure-1038520-

1.html?partner=sifma (quoting Federal Reserve Board Chairman Ben Bernanke as saying that "a key vulnerability of the [disintermediated or "shadow" financial] system was the heavy reliance . . . on various forms of short-term wholesale funding”); Viral V. Acharya \& S. Viswanathan, Leverage, Moral Hazard, and Liquidity, 66 J. FIN. 99, 103 (2011) (observing that short-term funding of long-term projects "played an important role in the financial crisis of 2007 to 2009 and the period preceding it").

76. Structural Investment Vehicle (SIV), MONEYTERMS.CO.UK, http://www.moneyterms.co.uk/siv/ (last visited Sept. 22, 2012) (explaining that structured investment vehicles buy long-term bonds, among others funded by the issuance of short- or medium-term debt). The business model of ABCP conduits is very similar to that of banks in that they borrow short-term and lend long-term. See, e.g., id. (providing a definition for structured investment vehicle).

77. Other ways to mitigate the risk "include better standards on match-funding coverage, better internal controls on collateral valuation and margining policies, and internalizing externalities (such as mandating privately funded systemic risk funds)." Regulating Shadows, supra note 75, at $33 \mathrm{n} .153$. The international Basel III capital accord takes a match-funding coverage approach, for example, introducing a liquidity coverage requirement that banks hold sufficient high-quality liquid assets to cover their total net cash outflows over 30 days and another requirement that banks maintain minimum yearly available amounts of stable funding. Jerome Walker et al., Reconciling the Dodd-Frank and Basel Committee Capital Requirements, 129 BANKING L.J. 627, 631 (2012).

78. Steven L. Schwarcz, Securitization, Structured Finance and Covered Bonds, China 2012 Lecture (Dec. 11, 2012), available at http://webcache.googleusercontent.com/search?q=cache:http://attach3.bdwm.net/ attach/boards/NSD/M.1354805735.A/\%E9\%99\%84\%E4\%BB $\%$ B61\%EF\%BC $\% 9 A \% E 8 \% A E \% B 2 \% E 5 \% B A \%$ A7\%E6\%96\%87\%E7\%A8\%BF.docx. 
term debt may not individually have large enough investments at stake to make it economically worthwhile for them to evaluate the transaction; therefore, they cannot accurately price the repayment risk. ${ }^{79}$ Liquidity providers, in contrast, should have enough at stake to make that evaluation economically worthwhile. 80

In theory, therefore, external credit enhancement and liquidity support can benefit Chinese securitization transactions. However, in practice, the employment of these methods in China may not be currently needed. Because securitization transactions in China often are payable from high-quality financial assets, the issued securities can usually be highly rated without credit enhancement. ${ }^{81}$ Moreover, Chinese securitization transactions rarely have publicly issued short-term funding, requiring liquidity support. ${ }^{82}$ Nonetheless, I understand that some Chinese transactions rely on privately issued shortterm funding to support the payment of long-term assets. ${ }^{83}$ Liquidity support could well be a helpful innovation in those transactions.

\section{B. Alternatives to Securitization}

An often-discussed alternative to securitization is covered bonds, which have some parallels to so-called asset-backed notes ("ABN") in China. First, I will discuss covered bonds, comparing covered bonds with securitization. Then, I will compare covered bonds with proposals for Chinese $\mathrm{ABN}$.

\section{Covered Bonds}

Covered bonds have a long history in European securities markets. ${ }^{84}$ By the end of 2008 , the amount of covered bonds outstanding in Europe alone was approximately $€ 2.38$ trillion, up from $€ 1.5$ trillion in 2003 . Covered bonds are relatively new, however, to U.S. securities markets. ${ }^{85}$

There is no formal international convention or treaty defining covered bonds. They are instead defined, de facto, by their characteristics. Essentially they are long-term debt securities that are secured by specific assets of the issuer of the bonds. The assets so constituting collateral are called "cover-pool" assets.

To the extent the cover-pool assets are insufficient to repay principal and interest on the covered bonds, investors in the bonds have an unsecured claim

79. Id.

80. Id.

81. E-mail from Liu Xiaoli, supra note 54. Because there is no current need for credit enhancement, the Chinese market lacks credit-enhancement firms. Id. There also may be questions under current Chinese law as to which firms could provide credit enhancement. Banks are not allowed to provide guaranties of debt securities. Id. Financial guaranty companies are not familiar with securitization transactions, and it is uncertain whether credit enhancement may be included in their permitted business scope. Id.

82. Id.

83. Email from Liu Xiaoli, supra note 54.

84. See Covered Bonds, supra note 2, at 563-64 (providing a general background and a detailed analysis of covered bonds).

85. Id. at 564. The first U.S. covered bond deal was issued by Washington Mutual in September 2006. Bank of America subsequently made a covered bond issuance in March 2007. Congress has been considering legislating a covered bond regime to stimulate covered bond issuance, but nothing has yet been enacted. See id. (describing Congress's intent to supplement or replace structured covered bond offerings). 
against the issuer for the insufficiency ["dual recourse"]. As with any granting of collateral, the cover-pool assets are deemed to remain on the issuer's balance sheet (i.e., they remain owned by the issuer) for accounting purposes. Unlike normal collateral, however, these assets are "ring-fenced" [effectively segregated from the issuer's estate] to give covered bondholders greater protection in the event of the issuer's bankruptcy. Additionally, weak coverpool assets are required to be replaced by good-quality assets throughout the life of the covered bonds [this requirement creates what is called a "dynamic" cover pool], thereby maintaining a requisite level of "overcollateralization"-a surplus of collateral value over indebtedness. To ensure this is all enforceable by covered bondholders against other creditors of the issuer, some countries have promulgated specific covered bond legislation (a "legislative" covered bond regime). Absent such legislation, covered bondholders must rely on contractual protections and related commercial law (a "structured" covered bond regime). 86

In addition, "Covered bond and securitization transactions have significant similarities. The most important is that both strive for bankruptcy remoteness-the goal of protecting covered bond investors in the event of the issuer's bankruptcy. Covered bond transactions strive to achieve bankruptcy remoteness through ring-fencing or by legislative fiat." 87 In Britain, Canada, and the United States, for example, ring-fencing involves the issuer creating a bankruptcy-remote, wholly owned SPV to purchase the cover-pool assets for the benefit of the covered bonds. ${ }^{88}$

Securitization transactions achieve bankruptcy remoteness by having the company originating the receivables (the "originator") transfer those receivables, in a "true sale" under bankruptcy law, to a bankruptcy-remote SPV-steps that can parallel ring-fencing. Another important similarity is that after covered bondholders are paid in full, and also after securitization investors are paid in full, any residual value from the transferred assets is returned for the benefit of other creditors. There are, however, several differences between covered bonds and securitization. 89

The primary distinctions are the dynamic cover pool and that covered bonds have dual recourse, whereas securitization constitutes non-recourse financing. "Another distinction is that, in covered bond transactions, the cover-pool assets typically remain on the issuer's balance sheet for accounting purposes whereas, in securitization transactions, it has been more typical for the transfer of assets from the originator to the SPV to be accounted for as a sale." 90

"[The] accounting distinction is somewhat artificial, however. Securitization transactions can be-and . . . increasingly are-structured as on-balance-sheet transactions. The absence of an accounting benefit does not undermine securitization's

86. Schwarcz, Covered Bonds, supra note 2, at 562-63.

87. Id. at 571 .

88. Id. at 570 .

89. Id. at 571 .

90. Id. 
key fundraising and risk-transfer functions." 91 The dynamic cover pool and dual recourse distinctions, however, are more critical. To understand why, compare the impacts of covered bonds and securitization on unsecured creditors:

In a securitization, if the overcollateralization is insufficient to repay investors, the investors [suffer] a loss because they only have recourse to assets that the SPV has already purchased. The pool of assets available for repayment is, in other words, effectively fixed or static. In contrast, in covered bond transactions, the cover pools are usually dynamic, requiring the covered bond issuer [to] continually . . . segregate new assets as needed to maintain overcollateralization-thereby enabling the covered bonds to continue to be paid in priority to unsecured claims. Covered bonds also go beyond securitization in their recourse. Whereas securitization transactions are nonrecourse, covered bonds have dual recourse. If, therefore, the [dynamic] coverpool assets are insufficient, covered bondholders have a recourse claim against the issuer. That claim, being pari passu with unsecured creditor claims, would further dilute [the recovery of the issuer's unsecured creditors]. As a result of the dynamic cover pool and dual recourse, covered bond transactions thus shift virtually all risk to [the issuer's unsecured creditors]. ${ }^{92}$

The extent to which risk should be allocated so asymmetrically is an important policy question that should be addressed by governments and market participants exploring covered bonds as an alternative to securitization.

\section{Comparing Covered Bonds with Chinese ABN}

As mentioned, $\mathrm{ABN}$ bear some common characteristics with covered bonds. In August 2012, China's National Association of Financial Market Institutional Investors (NAFMII), an organization authorized by the People's Bank of China (PBC) that exercises some supervisory power over the National Inter-Bank Bond Market (the main bond market in China), released a guide (the "Guide") on $\mathrm{ABN}$ issued by non-financial enterprises. ${ }^{93}$

ABN essentially can be viewed as debt securities with characteristics of assetbacked financing. The issuer of $\mathrm{ABN}$ has a recourse obligation to repay principal and interest to investors in the $\mathrm{ABN} .{ }^{94}$ The issuer also identifies certain of its assets to back its repayment obligation. ${ }^{95}$ The Guide does not dictate precise deal structures for ABN. Instead, it provides that " $\mathrm{t}] \mathrm{h}$ he issuer of asset backed note[s] shall design [a] reasonable deal structure, and the issuance shall not impair the interest[s] of its shareholders and

91. Covered Bonds, supra note 2, at 571-72.

92. Id. at $584-85$.

93. E-mail from Liu Xiaoli, supra note 54. Note that Chinese ABN is intended to be issued by nonfinancial enterprises. Covered bonds, in contrast, are usually, though not always, issued by banks. Furthermore, I understand that Chinese ABN are intended primarily to facilitate the financing of small- and middle-sized firms. Id. Nonetheless, the conceptual principles that I discuss are applicable regardless of what type or size of firm utilizes the covered bonds or $A B N$.

94. Id.

95. Id. 
creditors." 96

This deferral to reasonableness appears to result from a debate concerning promulgation of the Guide. Some parties wanted $A B N$ to merely be debt securities secured by the assets as collateral; other parties wanted $A B N$ to be issued by a newly created SPV, which (as described below in more detail) would hold and administer the assets to support the repayment of the ABN. ${ }^{97}$ This latter structure, the SPV model, was patterned on covered bonds. ${ }^{98}$

Under this Chinese SPV model, the issuer would issue ABN to investors. ${ }^{99}$ The issuer also would transfer, as settlor, assets to the trustee of a trust-SPV in exchange for a senior class and a residual subordinated class of trust certificates. ${ }^{100}$ The issuer would then transfer the senior trust certificates to investors holding the $A B N$, thereby effectively securing repayment of the $A B N$ by the assets in the trust. As consideration for receiving the $A B N$ and senior trust certificates, the investors would pay the issuer cash equal to the principal amount of the $A B N$. The $A B N$ thus would entitle those investors to two forms of recourse for repayment: first, a senior claim against the trust assets; ${ }^{101}$ second, a recourse claim directly against the issuer if the trust assets are insufficient to repay the investors. 102

Opponents of the SPV model argued, among other things, that the structure would be unfair because investors only pay money equaling the face value of the $\mathrm{ABN}$ but gain double rights. ${ }^{103}$ To the extent those opponents thought that investors could receive double payments, they would be logically wrong: the amounts they would be entitled to under both forms of recourse could not, in the aggregate, exceed the principal and interest owed to them. In other words, investors in ABN issued under the SPV model could receive no more than the amounts they would receive if they held secured bonds. 104

The SPV model does raise an aspect of the policy question that I raised when examining covered bonds as an alternative to securitization: whether dual recoursewhich is a feature of covered bonds and also a feature of the Chinese SPV model, though not a feature of securitization-allocates risk too asymmetrically. ${ }^{105}$ The SPV model would be much less problematic in this regard than covered bonds, however, if the SPV model did not also use a dynamic cover pool (which, for covered bonds, requires the covered bond issuer to continually segregate new assets as needed to enable the covered

96. Id.

97. E-mail from Liu Xiaoli, supra note 54.

98. Id.

99. Id.

100. For an explanation of trusts and trust law, see infra Part IV.B.3.

101. This senior claim would appear to be protected from the issuer's possible bankruptcy under Article 15 of China's Trust Act of 2001. See infra Part IV.B.5.

102. E-mail from Liu Xiaoli, supra note 54.

103. E-mail from Liu Xiaoli, supra note 41 .

104. ABN issued under the SPV model would be more advantageous to investors than secured bonds, however, because of the former's bankruptcy-remote structure. See supra note 101 and accompanying text (noting that ABN issued under the SPV model are secured by senior trust certificates in the trust-SPV). That structure would make it more likely that the ABN investors would be paid without a delay caused by the issuer's bankruptcy.

105. See supra notes $91-92$ and accompanying text (questioning whether dual recourse in covered bonds unfairly shifts too much risk to an issuer's unsecured creditors). 
bonds to continue to be paid in priority to unsecured claims $\left.{ }^{106}\right) .{ }^{107}$

Finally, because the SPV model utilizes a trust-SPV as its form of business organization, ${ }^{108}$ it calls into question how Chinese law treats commercial trusts. That question is especially interesting because China has a civil law system, whereas trusts are normally associated with a common law system; the latter more often addresses the type of divided ownership that enables separation between "beneficial" ownership by the trust and "legal" ownership by the trustee. ${ }^{109}$ This Article therefore closes by examining commercial trusts under Chinese law.

\section{Commercial Trusts Under Chinese Law}

Although originally used in China mainly for fund management and banking purposes, commercial trusts are increasingly being used in financial transactions. ${ }^{110}$ The shift began in 2001, when China passed the Trust Act of the People's Republic of China (the "Trust Act"). 111 This Act has made it possible to use trusts to engage in securitization transactions. ${ }^{112}$ The Act has also made it possible, as discussed above, to use trusts to engage in $\mathrm{ABN}$ transactions. ${ }^{113}$

106. See supra note 92 and accompanying text (observing the need for overcollateralization and segregation in the context of covered bonds).

107. Although I initially understood that the assets settled into the trust under the Chinese SPV model of $A B N$ would be fixed, or static, like securitization pools, I have been informed that parties might want the flexibility in some transactions to require additional assets to be settled into the trust if the initially settled assets become insufficient to repay the ABN. That would purport to create the equivalent, for the Chinese SPV model of $A B N$, of a covered bonds dynamic cover pool. However, I express no view, whether such additionally settled assets would have bankruptcy protection under Article 15 of the Trust Act. Cf. supra notes 101, 103 (discussing Article 15).

108. See supra notes $99-100$ and accompanying text (identifying a trust-SPV's trustee as the trustee of the Chinese SPV model and the issuer as the settlor).

109. Michael Milo \& Jan Smits, Trusts in Mixed Legal Systems, in TruSTS IN MDXED LEGAL SYSTEMS 13 (J.M. Milo et al. eds., 2001) (observing that, at that time, the type of divided-ownership characteristic of common law trusts did not exist in civil law countries); $c f$. RESTATEMENT (THIRD) OF TRUSTS ch.1, intro note (Tentative Draft No. 1, 1996) (noting that the trust is "peculiarly a product of the Anglo-American system"); Maurizio Lupoi, The Civil Law Trust, 32 VAND. J. TRANSNAT'L L. 967, 969 (1999) (observing that "there is a 'common core' at the basis of the Anglo-American trust"). But cf. Henry Hansmann \& Ugo Mattei, The Functions of Trust Law: A Comparative Legal and Economic Analysis, 73 N.Y.U. L. REV. 434, 444 n.31 (1998) (citing mixed-law jurisdictions including Louisiana, Quebec, and Scotland, as well as civil law jurisdictions including Japan, Lichtenstein, Israel, and several South American countries, that have adopted the trust).

110. See Charles Zen Qu, The Doctrinal Basis of Trust Principles in China's Trust Law, 38 REAL PROP. PROB. \& TR. J. 345, 349 (2003) (describing the advent of the Chinese trust and invested companies, which were intended to provide funding for the Chinese central government and were soon utilized by banks to operate in previously prohibited areas).

111. Id. at 347; see also Adam Hofri, Shapeless Trusts and Settlor Title Retention: An Asian Morality Play, 58 LOY. L. REV. 135, 135 (2012) (The Trust Act "created a stir in trusts scholarship by [neither requiring that title to the trust assets vest in the trustee nor specifying another location for that title.] The Act thus permits settlors to retain title in the trust assets despite having appointed another as trustee.").

112. See Mimi Hu, Developing Securitization Laws in China, 27 REV. BANKING \& Fin. L. 565, 588-90 (2008) (discussing how the Administrative Rules for Pilot Securitization of Credit Assets has impacted securitization in China). Chinese commercial trust law also derives from regulations promulgated by the Chinese Banking Regulatory Commission.

113. See supra notes $99-100$ and accompanying text. Commercial trusts are being used in China in other types of transactions. For example, real estate investment trusts (REITs) containing Chinese property are 
In common law countries, and in China as well, there is a distinction between commercial trusts used as business organizations and the related concept of a trust indenture. As explained below, depending on the business model, China's ABN transactions may involve both types of trusts.

\section{Trust Indentures}

A trust indenture is a contractual arrangement by which a trustee, usually a financial institution, acts as agent for one or more investors whose money is advanced as a loan to a company. ${ }^{114}$ In the United States, many trust indentures are entered into pursuant to the Trust Indenture Act of 1939, which requires independent trustees to protect the interests of investors in public offerings of bonds and other debt securities. ${ }^{15}$ Other trust indentures are private arrangements bargained for among sophisticated lenders, such as insurance companies, wherein one lender acts as agent for the others.

Although trust indentures create a fiduciary relationship based on agency law, some question whether they are actual trusts because there is ambiguity whether property is held in trust for beneficiaries. ${ }^{116}$ The transaction between the investors and the company is merely a loan, and the investors' claims against the company for repayment are monitored and enforced by the trustee as agent for the ratable benefit of the investors.

Although trust property may include choices in action such as investors' claims for repayment, the investors and generally not the trustee are deemed to be the holders of the loan claims that would constitute the trust assets. Nonetheless, the trustee monitors and often maintains records to register ownership of the loan claims, and, for administrative convenience, payments are generally made to the trustee for the benefit of the investors. While held by the trustee, those payments constitute trust property; and while payments are owed on the loan claims but not yet paid to the trustee, the trust indenture might be characterized as an instrument of trust or a promise to create a trust. A trust indenture

currently listed on the Hong Kong Stock Exchange, and it is expected that China will soon expand the availability of REITs beyond Hong Kong. DeloITte, CHINA REAL ESTATE INVESTMENT HANDBoOK 51, 81 (2012), available at http://www.deloitte.com/assets/Dcom-China/Local\%20Assets/Documents/Industries/ Real\%20estate/cn_RE_REIH2012_130312.pdf. REITs are special-purpose entities, organized as trusts, which issue securities to investors and use the proceeds to invest in real-estate properties. By purchasing REIT securities, investors can diversify to real estate without concentrated holdings, and they also gain liquidity by having the ability to sell their securities in a REIT secondary market. One can see the loose analogy between the REIT structure in real estate and the mutual fund structure in stock. In December 2008, the Chinese government announced support for pilot schemes for creation of Chinese REITs (called "C-REIT"s). In 2009, a REIT Working Group led by the Central Bank was established to develop the C-REIT regime. By 2012, the Beijing, Tianjin, and Shanghai local governments had proposed various C-REIT products (mainly inter-bank products) for possible approval by the State Council.

114. RichaRd T. MCDERMOTT, Legal ASPECTS OF CORPORATE FinANCE 144-45, 154-56 (3d ed. 2000).

115. Steven L. Schwarcz, Commercial Trusts as Business Organizations: Unraveling the Mystery, 58 BuS. LAw. 559, 569 (2003) [hereinafter Unraveling the Mystery]; see also 15 U.S.C. \$§ 77aaa-77bbbb (2012).

116. See, e.g., ReSTATEMENT (THIRD) OF TRUSTS $\S 2$, cmt. f ("A trust involves three elements: (1) a trustee, who holds the trust property and is subject to duties to deal with it for the benefit of one or more others; (2) one or more beneficiaries, to whom and for whose benefit the trustee owes the duties with respect to the trust property; and (3) trust property, which is held by the trustee for the beneficiaries.") (emphasis added). 


\section{therefore appears to be a hybrid form of a trust. ${ }^{117}$}

This same ambiguity appears to arise under Chinese trust law. The idea that a trust can be created without trust assets is confusing, and I have been informed that it is technically inconsistent with the Trust Act. ${ }^{118}$ Practically, however, financial regulators appear to be accepting the practice that the issuer of bonds or other debt securities may designate a financial institution to serve as an agent - sometimes called a bond agent - on behalf of the investors. ${ }^{119}$ That agent assumes duties similar to those of an indenture trustee in the United States. ${ }^{120}$ Likewise, in a non-SPV model of Chinese ABN transactions, the $\mathrm{ABN}$ would be issued as bonds or notes secured by collateral. ${ }^{121}$ Because investors in those securities would need a representative to act on their behalf, the issuer of the securities may need to designate a financial institution to serve as agent for that purpose, including holding the security interest in the collateral, monitoring the collateral, and, in case of the issuer's default, foreclosing on the collateral. ${ }^{122}$ In part that agent would be a typical bond agent with duties similar to those of an indenture trustee in the United States. ${ }^{123}$ I understand, however, that there is legal uncertainty in China whether an agent may hold a security interest in collateral - or, at least, whether the agent may be recorded on file as a security-interest holder-on behalf of third-party creditors. ${ }^{124}$

In Chinese securitization and SPV-model ABN transactions, the relevant business organization is an SPV, which may be a trust. ${ }^{125}$ Normally a trust company, which holds

117. Unraveling the Mystery, supra note 115, at 569-70.

118. E-mail from Liu Xiaoli, supra note 54.

119. Id.

120. Id.

121. Id.

122. $I d$.

123. See supra notes $119-120$ and accompanying text.

124. E-mail from Liu Xiaoli, supra note 54. Under Chinese law, a security interest cannot be separated from the right of payment; thus, because bondholders have the right of payment, the bondholders' agent technically cannot hold the related security interest. Even if a bondholder entrusts his bond and the corresponding security interest to the bond agent, some believe the bond agent cannot be recorded as the security-interest holder. However, if a bondholder transfers his bond to a trustee, the most widely accepted theory under Chinese law is that the trustee will become the bondholder, so the trustee can then be recorded as the security-interest holder. Id. In contrast, it is well-settled in the United States that an agent may hold a security interest in collateral on behalf of third-party creditors. The Uniform Commercial Code ("UCC") defers to actual practice, recognizing that commercial realities do not necessarily follow who holds title to property. See, e.g., U.C.C. $\S 9-202$ (2012) (stating that "the provisions of this article [9] with regard to rights and obligations apply whether title to collateral is in the secured party or the debtor"); U.C.C. $\$ 9-202$ official cmt. no. 2 (2012) (observing that the "rights and duties of parties to a secured transaction and affected third parties are provided in this Article [9] without reference to the location of 'title' to the collateral"); see also U.C.C. § 2509 official cmt. no. 1 (2012) (observing that the "underlying theory of these sections on risk of loss is the adoption of the contractual approach rather than an arbitrary shifting of the risk with the 'property' in the goods"); U.C.C. $\$ 2-401$ (2012) (providing that "each provision of this Article [2] with regard to the rights, obligations and remedies of the seller, the buyer, purchasers or other third parties applies irrespective of title to the goods except where the provision refers to such title"). The UCC thus makes it clear that a security interest in collateral may be granted to an agent or trustee on behalf of creditors. U.C.C. $\S 9-102$ (2012) (providing that a "secured party" includes a "trustee, indenture trustee, agent, collateral agent, or other representative in whose favor a security interest ... is created or provided for").

125. See supra notes 99-100,112 and accompanying text (discussing how an issuer would transfer assets 
a trust business license, will serve as the trustee. ${ }^{126}$ Using a trust as a form of business organization raises additional issues, discussed below.

\section{Trusts Used as Business Organizations}

Although traditionally used in gratuitous transactions, ${ }^{127}$ trusts are now widely employed (including in China) as business organizations in commercial and financial transactions, including securitization (and soon contemplated to include $A B N$ ) transactions. ${ }^{128}$ In these transactions, a party (the "settlor") transfers assets to the trust in exchange for payment. ${ }^{129}$ The settlor also typically retains a residual interest, entitling it to retain any trust assets remaining once the business transaction is concluded. ${ }^{130}$ Investors in the trust, as senior claimants, bargain to get their money back with interest. ${ }^{131}$

These steps establish a trust in which there is "a fiduciary relationship with respect to property [the assets transferred to the trust], arising as a result of a manifestation of an intention to create that relationship and subjecting the person who holds title to the property [the trustee] to duties to deal with it for the benefit of' the investors. ${ }^{132}$ The trust has certain similarities to a corporation-both forms of business organization separate ownership by the residual beneficiaries (the settlor in case of a trust, shareholders in case of a corporation) from management (the trustee in case of a trust, the board of directors in case of a corporation) and impose fiduciary duties on management to act for the benefit

to the trustee of a trust-SPV, and how these trusts can engage in securitization transactions).

126. E-mail from Liu Xiaoli, supra note 54. To serve as the trustee in securitization transactions, the trust company would need special qualification as approved by the China Banking Regulatory Commission. Id.

127. See, e.g., John H. Langbein, The Contractarian Basis of the Law of Trusts, 105 YALE L.J. 625,632 (1996) ("Trusts are gifts.").

128. Supra notes 112-113 and accompanying text; see also John H. Langbein, The Secret Life of the Trust: The Trust as an Instrument of Commerce, 107 YALE L.J. 165, 172 (1997) (noting that perhaps trillions of dollars of mortgage, credit card, automobile, and student loan debt is financed through trusts). Trusts have also become a primary tool for investing pension moneys. Id. at 168-69. They also are the preferred form for structuring mutual funds. Id. at 171 (footnotes omitted); see also Jeffrey M. Laderman, Your Guide to Mutual Funds, BlOOMBERG BusinessweEK (Feb. 2, 1997), http://www.businessweek.com/stories/1997-02-02/yourguide-to-mutual-funds ("In 1996, some $\$ 223$ billion was handed over to equity-[mutual]-fund managers . . . . It's almost as much as the gross domestic product of Sweden.").

129. See Unraveling the Mystery, supra note 115, at 562 (comparing the difference between commercial and gratuitous trusts).

130. Id. This can be illustrated by a typical example from structured finance. A company settles a trust by transferring financial assets to the trust in return for payment in the form of trust certificates and a bargained-for residual interest in the trust. The company then raises funds by selling the trust certificates to capital market investors, who buy the certificates expecting that the trust assets will generate sufficient cash to repay their investment plus the contractual rate of return specified in the certificates. The residual interest entitles the company to any assets remaining in the trust once the certificates are paid in full. This residual amount can be significant. To ensure repayment, capital market investors usually demand that the amount of assets conveyed to the trust be well in excess of the minimum necessary to repay such investors. Alchemy, supra note 3 , at 141 . The residual claim to these assets after the investors are repaid therefore is a valuable property right, which the settlor is unwilling to give up. Id.

131. Unraveling the Mystery, supra note 115 , at 563.

132. RESTATEMENT (THIRD) OF TRUSTS $§ 2$ (Tentative Draft No. 1, 1996). Although the Restatement itself does not specifically address commercial trusts, see $i d . \S 1, \mathrm{cmt}$. b, and $\S 5, \mathrm{cmt}$. 1 (discussing the use of trusts that is not within the scope of the Restatement). 
of the investors. Similarly, both forms of business organization provide for limited liability. For example, investors may claim (absent breach of trust) only against the trust assets, not against personal assets of the trustee; ${ }^{133}$ in addition, the trustee's personal creditors may not claim against the trust assets. ${ }^{134}$

Nonetheless, significant differences exist between trusts and corporations operating as business organizations. To understand the differences, consider two fundamental perspectives by which one can think about a business organization: When is the organization seen to exist (its "legal existence")? And how is the organization governed (its "governance"135)? 136

"Commercial trusts are not always recognized as having separate legal existence." 137 In contrast, "corporations almost always are recognized as having separate existence at law."138

"[A] trust's lack of legal existence could be troublesome if its beneficiaries are concerned that the settlor transferring assets to the trust might go bankrupt. If bankruptcy law did not recognize the trust, the assets thought to be conveyed to the trust [could] still belong to the bankrupt company."139 That is, bankruptcy law would not necessarily recognize the independence of the trust assets from the settlor.

I understand that a trust's lack of existence may be less of a bankruptcy risk in China than in the United States. Although it has not yet been legally tested in China, the Trust Act provides, in Article 15, that "[ $t]$ rust assets are distinguished from the settlor's other non-entrusted assets. After the creation of a trust and under the circumstance that the settlor [is] announced bankrupt, ... if the settlor is not the only beneficiary of the trust, the trust shall continue, and the trust assets shall not be treated as the heritage or liquidation assets." 140

From the standpoint of the second perspective, governance, commercial trusts are seen to be static entities with passive managers, the trustees of the trust. ${ }^{141}$ "This contrasts sharply with corporations, whose managers tend to be aggressive and

133. RESTATEMENT (SECOND) OF TRUSTS $§ 204$ (1959) (discussing non-liability of trustee for loss in absence of breach of trust).

134. Id. $\S 266$ (stating that a person to whom trustee has become liable cannot reach trust property). Accord Convention on the Law Applicable to Trusts and on Their Recognition art. 2, § a, Hague Conf. Private Int'l L., http:/www.hcch.net/upload/conventions/txt30de.pdf (last visited Oct. 17, 2013) (providing that a trust's "assets constitute a separate fund and are not a part of the trustee's own estate").

135. See Stephen M. BAINBRIDGE, CoRPoration LAW AND ECONOMICS 192 (2002) (the term "governance" is commonly used to describe an organization's "system that facilitates efficient decisionmaking").

136. See generally Unraveling the Mystery, supra note 115 (examining a third way to think about a business organization: what effect does the organization have on its surroundings and vice versa, or the organization's "exogenous effects").

137. Id. at 574 .

138. Id.

139. Id. at 575 .

140. Translation provided by Liu Xiaoli. Zhonghua Renmin Gongheguo Xintuo Fa [Trust Law of the People's Republic of China] (promulgated by the standing committee of the Ninth National People's Congress at the People's Republic of China, Apr. 28, 2001, effective Oct. 1, 2001), at Article 15 (China) (the official translation of the law is available at English.gov.cn/laws/2005-9/12/content_31114.html).

141. Unraveling the Mystery, supra note 115, at 575 ("[C]ommercial trusts tend to be static entities, and their managers (trustees) often are perceived as passive."). 
opportunistic to take advantage of business opportunities." 142 I believe this reflects the most fundamental distinction between trusts and corporations: the degree to which assets need to be placed at risk in order to satisfy the expectations of residual claimants.

To understand this distinction, note that in a corporation the residual claims, which are evidenced by shares of stock, are sold to third-party investors ("shareholders"). ${ }^{143}$ The shareholders expect a rate of return that compensates them for the money they voluntarily put at risk. ${ }^{144}$ If that rate of return is not forthcoming, they will not invest and the system of shareholder corporate finance would collapse. ${ }^{145}$ Therefore, it is essential that corporations engage in business ventures that are likely to increase their profitability. 146

In contrast, "a corporation's senior claimants (its creditors) will be paid principal and interest (the latter being their contractual rate of return) so long as the corporation is solvent." 147 However, allowing a solvent corporation to engage in business ventures to increase profitability brings no benefit to creditors, whereas failure of the venture might bring a risk of insolvency and hence loss. ${ }^{148}$ Further, "[t]he fundamental goals of a corporation's shareholders (residual claimants) and creditors (senior claimants)" therefore compete. 149 "Corporate law resolves these competing goals by allowing managers- - the corporation's board of directors - to take risks in order to maximize corporate profitability (and thus shareholder return) so long as the corporation is not insolvent". ${ }^{150}$ For this reason, the board of directors is responsible to shareholders but not creditors, absent insolvency. ${ }^{151}$

Because trust law developed when most trusts were gratuitous, not commercial, trust law does not directly address conflicts between senior and residual claimants. In gratuitous trusts, the expectations of the claimants, in practice, tend to be consistent: to preserve the value of the trust assets. ${ }^{152}$ Trust law, therefore, generally imposes a duty of impartiality: "if a trust has two or more beneficiaries, the trustee shall act impartially." 153 However, this duty does not always clearly inform commercial trusts, which are more likely to have conflicts between senior and residual claimants.

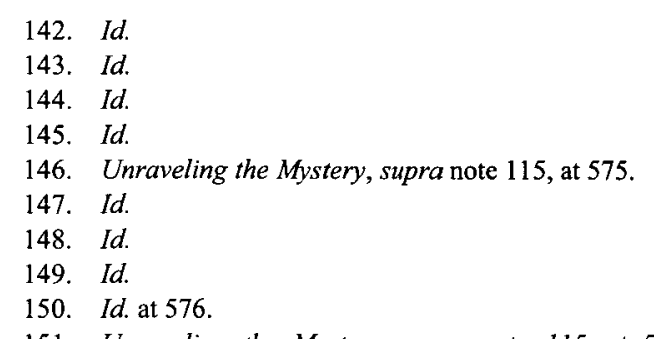

151. Unraveling the Mystery, supra note 115, at 576 (the board of directors is responsible, absent insolvency, only to the shareholders and not the creditors).

152. See, e.g., IIA AUSTIN W. SCOTT \& William F. Fratcher, THE LAW OF Trusts $§ 176$ (4th ed. 1987) ("It is the duty of the trustee to use care and skill to preserve the trust property."). For example, a gratuitous trust with no residual claimants avoids conflict by having only senior claims. A gratuitous trust where the settlor is the only residual claimant-as in settlor transferring a life estate in assets for the benefit of third party, with the residual to the settlor-rarely creates a significant conflict because the settlor, unlike a corporate shareholder, normally would not expect a risk-weighted return on its claim. Even a gratuitous trust with third-party residual claimants does not have the degree of conflict that occurs between a corporation's creditors and shareholders.

153. RESTATEMENT (THIRD) OF TRUSTS $\S 79$ (2007) (discussing both the duty of impartiality; income productivity). 
In commercial trusts, for example, the settlor's interest, as residual claimant, is the inverse of the beneficiary's interest, as senior claimant-that is because each dollar used to pay the senior claimant reduces by a dollar the amount available to return to the residual claimant. So long as there are no third-party residual investors, this conflict is rarely problematic; a settlor-residual claimant, unlike a corporate shareholder, does not ordinarily expect a risk-weighted return on its claim. Instead, its business goal is simply to retain any surplus value in the trust's assets. ${ }^{154}$ Significant conflicts can occur, however, when commercial trusts have third-party investors with different priority claims against the trust- - such as a securitization transaction where a trust sells different classes, or "tranches," of certificates to third-party investors. It is common, for example, for such a commercial trust to issue a dozen or more tranches, each tranche having its own relative priority of payment. To understand the problem, consider a class of senior investors and a class of subordinated investors that are secured by, and thus payable from, the same collateral held by the trust.

In deciding whether and how to exercise remedies, the trustee would have to attempt to understand and balance the interests, after default, of the senior and subordinated investors. Even given a duty of impartiality, there is relatively little guidance on how that should occur. The English High Court of Justice was faced with such a conflict several years ago when Orion Finance Corporation, a huge Cayman Island structured investment vehicle (SIV), defaulted on its payment obligations to senior investors. ${ }^{155}$ With billions of dollars at stake, the senior investors wanted the trustee to foreclose on the financial assets owned by the SIV, which at the then-collapsed market prices would have yielded barely enough money to repay the senior investors, leaving nothing for subordinated investors. ${ }^{156}$ That could have severely compromised the financial condition, and possibly the ultimate viability, of the two large financial institutions that held the subordinated securities. 157

The subordinated investors, instead, wanted the trustee to delay foreclosure, hoping to be repaid (or at least to receive some recovery) from a subsequent rise in prices of the underlying financial assets or from collections on those assets. ${ }^{158}$ Neither the applicable collateral documents (in this case, a security agreement governed by New York law) nor the applicable foreclosure law (the New York Uniform Commercial Code) provided the trustee with clear answers. ${ }^{159}$

The English court held that the senior creditors had no express contractual right to direct the trustee regarding foreclosure. ${ }^{160}$ It also concluded, applying New York law, that the collateral is "held for the benefit of all the Secured Parties," meaning the

154. Unraveling the Mystery, supra note 115 , at 578 .

155. See Bank of N.Y. v. Mont. Bd. of Invs., [2008] EWHC (Ch) 1594, [16]-[28] (Eng.), available at http://www.bailii.org/ew/cases/EWHC/Ch/2008/1594.html (last visited Oct. 17, 2013).

156. Bank of N.Y., [2008] EWHC (Ch) 1594 [25]-[27].

157. The author was an expert witness in this case for these financial institutions, as to matters of fiduciary law and foreclosure law. See id. [31] (discussing that the Security Trustee served an expert report from a professor at Fordham University).

158. See id. [27] (identifying that the subordinated creditors directed the Security Trustee to refrain from liquidating any collateral).

159. See id. [6]-[7] (explaining the issues at stake in the case).

160. Id. [43], [55]-[56], [61]. 
subordinated as well as the senior investors. ${ }^{161}$ Thus, the trustee "is not the mere agent of the creditors, but is required to exercise [] discretion." 162

If this same issue were to arise in a trust governed by Chinese law, its resolution might be different. I understand from discussions at a conference at the Shanghai Institute of Foreign Trade, that the trustee of a Chinese trust contract may have the discretion to quickly dispose of the trust assets in case of default, despite the possible loss this may cause to non-senior claimants. ${ }^{163}$ However, this issue has not yet been judicially resolved in a disputed case. 164

As previously discussed, the dilemma of a trustee with conflicting obligations is a real problem because of its broad scope and the fact that trustees are increasingly resorting to litigation, with all of its associated costs, to determine their responsibilities. ${ }^{165}$ The problem is also real because, by focusing on limiting their liability, trustees are acting in ways that can be suboptimal for some or all of their beneficiaries. Sometimes those suboptimal actions can have significant social costs that extend far beyond the actual beneficiaries, such as foreclosing on defaulted securitized residential mortgages even when a workout would create more value and preserve home ownership. Elsewhere I have argued that existing law gives trustees little guidance on balancing these conflicting interests of third-party investors, and that trustee-governance law needs to evolve in order to adequately address these commercial trust issues. ${ }^{166}$

161. Bank of N.Y., [2008] EWHC (Ch) 1594, [58].

162. Id.

163. Conference on commercial trusts at Shanghai Institute of Foreign Trade (Dec. 5, 2012).

164. Id.

165. Bank of N.Y., [2008] EWHC (Ch) 1594, [59].

166. See generally Steven L. Schwarcz, Fiduciaries with Conflicting Obligations, 94 MINN. L. REv. 1867 (2010) (addressing the dilemma of fiduciary acting for parties who have conflicting commercial interests); see also Schwarcz \& Sergi, supra note 53 (inquiring into the standard of care for indenture trustees). The prudent man rule of trust law generally requires the trustee "to use care and skill to preserve the trust property." $2 \mathrm{~A}$ AUSTIN W. SCOTT, THE LAW OF TRUSTS $\S 176$ (4th ed. 1987). This is primarily a negative duty, meaning a trustee should refrain from exposing trust beneficiaries to unreasonable risks. Thus, the trust law duty focuses more on preserving, rather than increasing, the value of the assets held in trust. Id. $\S 174$ (stating that "[i]n making investments the trustee is under a duty ... [to] use the caution of one who has primarily in view the preservation of the estate entrusted to him"). To that extent, the trustee's duties under trust law are ministerial, requiring "minimal managerial discretion and cost." Unraveling the Mystery, supra note 115, at 581. In contrast, the duty of corporate directors under the prudent man rule is to maximize value. As a result, trustees are normally cautious and conservative, whereas "risk-taking decisions are central to the [corporate] director's role." ANN. MODEL BUS. CORP. ACT $\S 8.30$ introductory cmt. (2005). To encourage corporate directors to make decisions that inherently involve risks, corporate decision making is normally protected by the business judgment rule, which presumes rationality and thus immunizes directors against liability for losses caused by decisions made by non-conflicted directors acting in good faith. See PRINCIPLES OF CORPORATE GOVERNANCE $\S 4.01 \mathrm{cmt}$. d (1994) (observing that the business judgment rule attempts to grant corporate directors the flexibility necessary to fulfill their duty by engaging in "venturesome business activity"). I argue that trustees of commercial trusts should also have the protection of a business judgment rule, at least in circumstances where their job involves maximizing value, rather than merely preserving it. This same principle-maximizing value-also serves as a key justification for the corporate business judgment rule. 


\section{CONCLUSIONS}

Securitization and associated forms of structured financing, including covered bonds and asset-backed notes, can be valuable and efficient tools for raising financing. If misused, however, these tools can increase financial risks, as illustrated by securitization's role in the global financial crisis. I hope that this Article can help to add clarity and give lessons from experience to the development of these modes of financing in China-an extraordinary nation, facing extraordinary economic challenges and opportunities. 